\title{
The Position of prasamkhyana as an Aspect in the Theory of Practice by Sureśvara
}

\section{Masahiko TANIGUCHI}

The study on hand aims at clarifying the content and position of prasamkhyāna in the theory of practice by Sureśvara (c. 720-770 AD)

First, in the Sambandhokti, that is, the introductory prose section of the Naiskarmyasiddhi (hereafter, abbreviated as Nais) ${ }^{1)} 3.90$ that outlines Sureśvara`s criticism of the exponents of prasamkhyana, a certain exponent explains prasamkhyana as follows :

"It is said that prasamkhyana is the repeated application of the mind to reasoning by means of the logical method (yukti) called anvayaryatireka, which is its turn is applied to the meaning of revelatory sentences like 'That thou art' in the Śruti. And when practiced, it gives rise to perfect knowledge by increasing the correct knowledge and not by increasing the concentration on one single object" (for reasons of space only the translation is presented here).

According to this assertion, the corect knowledge to be increased does already exist in man before prasamkhyana is practiced. Further, as regards anvavavvatireka, it represents a method of interpretation of the Śruti, and Sureśvara goes so far as to assert that this is indispensable for obtaining an understanding of vākyārtha (meaning of revelatory sentences) ${ }^{2}$. Sureśvara refutes the above-mentioned argument in Nais 3.90 as follows :

(90) What arises from accumulating abhyassa is only the concentration of mind. Actually the various means of knowledge do not bring about the knowledge of its objects as a result of repetition.

Here abhyassa is used in place of prasamkhyanna. Furthermore, another exponent of prasamkhyanna appears in Nais 3.123 who asserts that the revelatory sentences present the knowledge of àtman only indirectly, and in Nais 3.124 Sureśvara' s response goes as follows :

However, we do not support the view that correct understanding is produced by prasamkhyāna, 
which represents nothing but the repetition of reasoning (by logical method) and of the revelatory sentences of the Śruti. "Wherefore?"

(124) If reasoning and revelation sentences did not bring about correct knowledge for him earlier, what sort of completely new thing (apürra) could result from their repetition?

Afterwards however, he makes a turn and approves prasamkhyāna conditionally:

Then, if someone says that he is not able to maintain his life without prasamkhyāna, we will acknowledge it only in śravana (hearing) etc. "On what conditions?"

(125) We will accept the method of repetition in prasamkhyāna in hearing contents related to àtman, Man will come to an understanding after correctly hearing what he heard only a little bit or fragmentarily.

The fact that the term prasamkhyāna is simply replaced by abhvāsa, and the wording "the method of repetition in prasamkhyāna" in Nais 3.125, suggest that he did not acknowledge the method of practice as advocated the exponents of prasam$k h y \bar{a}$ a but rather approved the method of "repetition" contained therein.

However, according to preceding studies ${ }^{4)}$ the below-mentioned points have already been clarified. Sureśnara regards prasamkhyāna as an extremely preliminary and auxiliary element in the practice and acknowledges its usefulness for physical and mental actions like religious rites or meditation and logical reasoning. In practice prasamkhyāna is carried out on the same stage together with sravana and manana (reasoning); as a result prasamkhyāna enables those, who cannot understand $v \bar{a}$ kyārtha in a single śravana and manana, to obtain an understanding of this religious teac-hing. According to preceding study by Shoun Hino ${ }^{5)}$ the point is clarified that for Sureśvara, as a consequence of practicing the repetition of sravana and manana, the state in which an understanding of vākyārtha has been obtained is nididhyasana, and what makes up the term manana is nothing but anvayavyatireka.

From it the fllowing conclusion can be derived.

Sureśvara takes out only the element of "repetition" from the prasamkhyāna and calls the "repetition" of sravana and manana, which are mental acts for illuminating vakyārtha, "prasamkhyāna". Therefore, in the explanatory descriotion of up to 14 stages in the sambandhokti in Nais 1.52 the 10th stage of the "practice of yoga", yogābhyāsa ${ }^{6)}$, which contains śravana and manana, again includes also prasamkhy$\bar{a} n a$. However, śravana and manana are required for attaining ātman, and especially 
The Position of prasamkhyāna as an Aspect in the Theory of Practice by Sureśvara

anvayavyatireka that constitutes the term of manana is indispensable for clarifying $v \bar{a} k v \bar{a} r t h a$. On one side the degree of necessity of prasamkhyāna, which is their " repetition", is determined by the capability of the practitioner. For those who understand vākvārtha in only one single śravana and manana the repetition is therefore not necessary. As a result prasamkhyāna, while being in the very same way a mental action, ranks lower than anvayavyatireka. In addition, a point of analogy can also be discovered between religious rites and prasamkhyāna. Because religious rites that contribute to the purification of mind, too, are in their turn determined by the purity of the practitioner as regards their degree of necessity.

1) The text uses the following: The Naișarmyasiddhi of Sureśrarācārya with the Candrikā of Jñanottama, Ed. the late Colonel G. A. Jacob. revised edition by M. Hiriyanna. Bombay Sanskrit and Prakrit Series No. 38, 1925. 4th edition. Poona : Bhandarkar Oriental Research Institute, 1980.

2) Nais 2.9. The following research exists about the anvayaryatireka of Śankara and Sureśvara : Hacker, P. [1950] Untersuchungen über. Texte des frühen Advaitarāda, 1. Die Schüler Śankaras. Mainz: Verlag der Wissenschaften und der Literatur, 1950, p. 1980, pp. 1999-2000; Mayeda, Sengaku [1978] "Sureśvara and 'Tat Tvam Asi," Journal of Indian and Buddhist Studies, Tokyo, 27-1, pp. 70-77 (in Japanese) Shoun Hino [1982] Sureśvara's Vārtika on Yājñavalkya-maitreyī Dialogue, B!̣hadāranyakopanișad 2.4 and 4.5.2nd ed. Delhi: Motilal Banarsidass, 1991, pp. 47-53; Halbfass, W. [1991] Tradition and Reflection. Albany: State University of New York Press, 1991, pp. 162-180.

3) "prasamkhyāne śrutāv asya nyāyo 'stv āmredanātmakah"

4) M. Hiriyanna [1925] Introduction to the text shown in note 1 ; Introduction, pp. xiii-xxx ; Hacker loc, cit. pp. 1992-2012; Alston, A. J. [1971] The Realization of the Absolute, the "Naișkarmyasiddhi" of Śri Sureśvara, translated by A. J. Alston. 2nd ed. London: Shanti Sadan, 1971 ; R. Balasubramanian [1988] The Naiskarmyasiddhi of Sureśvara. Ed. R. Balasubramanian. Madras University Philosophical Series No. 47. Radhakrishnan Institute for Advanced Study in Philosophy, University of Madras, 1988.

5) Hino, loc. cit., pp. 22-25: Hino [1981] "Sureśvara on nididhyāsana," Journal of Indian and Buddhist Studies, Tokyo, 29-2, pp. 164-165 (in Japanese)

6) Hacker, loc. cit., p. 1980; pp. 1995-1999; Hino, loc. cit, pp. 8-21.

〈Key Words〉 Sureśvara, prasaṃkhyāna, Naiṣkarmyasiddhi

(Graduate Student, Tokyo University) 